\title{
The Role of Cities in the Integration of Immigrants in Europe
}

\begin{abstract}
In the era of migration, cities play an important role in integrating immigrants and promoting social cohesion. Sometimes they create and implement integration policies different from these at a national level. The state-run civic integration programs question the thesis of the growing role of cities as these programs have resulted in centralizing integration policies and reducing their role. In recent years, large European cities have been implementing a cultural diversity management model referred to as "intercultural integration". They have also adopted mainstream policies targeted at the entire population. In terms of immigrant integration policy Polish large cities have recently been following a pattern set by their Western European counterparts. This results from the availability of European funds and trends towards cultural diversity rather than challenges.
\end{abstract}

Keywords: Cities, Integration of Immigrants, Immigrants

\section{Introduction}

The integration of immigrants into a host society has become a very important issue in the face of the problems connected with the intensive influx of immigrants to Europe. Different approaches and practices have been developed to integrate immigrants into host societies. They include various methods of assimilation, the reception of "guest workers", multiculturalism and integration defined as a two-way process of the adaptation of immigrants and the host society. ${ }^{1}$ Due to the research deficit, it is uncertain how

\footnotetext{
^ Lucyna Rajca - Jan Kochanowski University in Kielce, e-mail: lucyna.rajca@ujk. edu.pl, ORCID: 0000-0002-3947-1729.

1 R. Stefańska, Między multikulturalizmem a asymilacja? Polityki integracyjne w Europie (Between Multiculturalism and Assimilation? Integration Policies in Europe), in:
} 
these country-level policy models reflect the daily reality of intercultural interaction in cities. Therefore, research into the local dimension of migration policies is needed to help verify concepts and models in the light of new empirical findings. ${ }^{2}$ Migration policies are developed at a European and national level, whereas integration policies are implemented in cities even if some of their mechanisms are established at higher levels of public authority. ${ }^{3}$ In recent years, the growing importance of cities in the integration of immigrants has been observed. As the vast majority of immigrants settle in urban areas, various problems emerge. Therefore, cities which are frequently affected by the consequences of integration failures are willing to develop effective local integration practices.

Cities can play their role in the integration of immigrants - as Dirk Gebhardt emphasizes - by providing them with access to socio-economic, political and cultural rights. Although these rights are usually granted by the state, municipalities have considerable freedom in defining access criteria in areas that are under their control, such as childcare, adult education, housing, and cultural facilities (services). Cities can also - as Dirk Gebhardt points out - contribute to respecting human and civil rights by, for example, raising awareness of non-discrimination, facilitating access to political rights by involving immigrant organizations in order to tackle low voter participation and increase immigrant political participation, and allowing immigrant organizations to participate in local decision-making processes and allowing immigrants to provide services to a city's inhabitants. ${ }^{4}$ Therefore, cities have the capacity to control the integration of immigrants in a more inclusive or, on the contrary, restrictive direction.

The aim of this article is to present the role of European cities in the process of immigrant integration. Questions about the integration model and urban policy concepts will be addressed, and also whether

Problemy integracji imigrantów. Koncepcje, badania, polityki (Problems of Immigrant Integration. Concepts, Research, Policies), eds. A. Grzymała-Kazłowska, S. Łodziński, Warszawa 2008, pp. 123-130.

2 M. Borkert, T. Caponio, Introduction: the local dimension of migration policymaking, in: The Local Dimension of Migration Policymaking, eds. T. Caponio, M. Borkert, Amsterdam 2010, pp. 11-13.

3 R. Penninx, Decentralizacja polityk integracyjnych. Zarzadzanie migracja w miastach, regionach i spotecznościach lokalnych (Decentralising Integration Policies. Managing Migration in Cities, Regions and Localities), in: Laboratoria integracji. Obserwacje i notatki praktyczne (Integration Laboratories. Observations and Practical Notes), eds. M. Bieniecki, M. Pawlak, Gliwice 2012, p. 23.

${ }^{4}$ D. Gebhardt, Re-thinking urban citizenship for immigrants from a policy perspective: the case of Barcelona, "Citizenship Studies", vol. 20, no. 6-7/2016, pp. 846-866. 
these concepts coincide with those defined at the national level. European cities with extensive experience with immigrants have been selected for analysis. The article firstly presents trends occurring in urban integration policies. Subsequently, the issue of compliance or divergence between urban policies and national policies is considered. The next sections are devoted to urban integration initiatives in Poland and the analysis of the thesis on the growing role of cities in integration policy. The final part highlights the main research findings and presents conclusions. ${ }^{5}$ The article is based on literature analysis, but it also draws on documents.

\section{Trends in Urban Integration Policies}

Describing the experiences of European cities in the field of immigrant integration, Patrycja Matusz Protasiewicz distinguished two stages of integration activities. Firstly, city authorities introduced solutions in socio-economic areas such as the labour market, the education system, and the housing system. In the second stage, which took place much later, there occurred manifestations of hostility towards immigrants demonstrated by indigenous people. Local communities put pressure on the authorities, demanding the solve integration problems. ${ }^{6}$ In the second stage, the cities' activities involved cultural and religious issues important to immigrants. Experience shows that social assistance alone is not sufficient for the integration of immigrants.

Several phases of urban integration policy have been distinguished in the literature: the lack of any special policy towards migrants and an interim response to problems, a policy designed for temporary solutions in relation to "guest workers", an assimilation policy aimed at integrating migrants by minimizing differences in various aspects, and a pluralist policy that seeks to ensure and even celebrate the identity of ethnic groups and their empowerment ${ }^{7}$ have all been distinguished. In recent years,

5 The article is an English version of the authors' article entitled: Rola miast $w$ integracji imigrantów - koncepcje miejskiej polityki integracyjnej (The role of cities in the integration of immigrants - concepts of urban integration policy), „Samorząd Terytorialny”, no. 7-8/2018, pp. 79-87.

6 P. Matusz-Protasiewicz, Rosnaca rola poziomu lokalnego w kreowaniu polityki integracji imigrantów w Unii Europejskiej (The Growing Role of the Local Level in the Development of Immigrant Integration Policy in the European Union), „Central and Eastern European Migration Review", vol. 2, no. 2/2013, pp. 75-97.

7 M. Alexander, Local Policies toward Migrants as an Expression of Host-Stranger Relations: A Proposed Typology, "Journal of Ethnic and Migration Studies", no. 29 (3)/2003, pp. 411-430. 
attention has been drawn to the emergence of the next phase of the policy referred to, among others, as "intercultural" or "post-multicultural" ${ }^{8}$ It is characterized by focusing on the individual rather than ethnic groups and embracing other aspects of diversity such as gender, disability, and sexual orientation. Increasingly, cities are withdrawing from providing funds for cultural activities addressed and organized by a specific ethnic group while support is given to projects seeking to connect various groups forming the city's community and promoting interaction. Such activities are organized, for example, by the authorities of Antwerp or Amsterdam. ${ }^{9}$

In most European cities there has been a trend in recent years to move away from immigrant-oriented policies towards adopting mainstream policies aimed at the entire population. ${ }^{10}$ This trend is noticeable even in the absence of national integration guidelines. For example, the two Danish cities of Aarhus and Copenhagen developed mainstream policy before the Danish government adopted this type of integration strategy in 2011 and placed the responsibility for it on the government. ${ }^{11}$ The trend of mainstreaming through governance is currently being observed in Europe. National, regional and local authorities strengthen horizontal and vertical cooperation. Civil society organizations, as well as the private sector (by not discriminating against immigrants), play an increasingly important role in the integration of immigrants, especially at the local and regional level. ${ }^{12}$ Mainstream policies are innovative forms of urban governance, but the question arises as to whether they can address inequalities based on race or ethnic discrimination. Barcelona's experience shows that this

8 M. Schiller, Paradigmatic Pragmatism and the Politics of Diversity, "Ethnic and Racial Studies", no. 38 (7)/2015, pp. 1120-1136.

9 P. Matusz-Protasiewicz, Sposób ksztattowania relacji międzygrupowych na poziomie lokalnym, ze szczególnym uwzględnieniem społeczności muzutmańskiej na przykładzie Antwerpii (Belgia) i Amsterdamu (Holandia). Doświadczenia z badania CLIP 2009-2011 [A way of developing intergroup relations at the local level, with particular emphasis on the Muslim community using the example of Antwerp (Belgium) and Amsterdam (Netherlands). Experiences from the CLIP 2009-2011 study], in: Wokót problematyki migracyjnej. Kultura przyjęcia (Around Migration Issues. The Culture of Immigrant Reception), eds. J. Balicki, M. Chamarczuk, vol. 7, Międzyinstytutowy Zakład Badań nad Migracją Uniwersytet Kardynała Stefana Wyszyńskiego, Warszawa 2013, pp. 41-56.

$10 \mathrm{D}$. Gebhardt, When the state takes over: civic integration programmes and the role of cities in immigrant integration, "Journal of Ethnic and Migration Studies", vol. 42, no. $5 / 2016$, p. 745 .

11 E. Collett, M. Petrovic, The Future of Immigrant Integration in Europe. Mainstreaming Approaches for Inclusion, Brussels 2014, p. 13.

12 Ibidem, pp. 22-23. 
policy did not lead to effects of inclusion effects, because urban services failed to compensate for the disadvantages of immigrants. ${ }^{13}$

The literature proves that as a result of the criticism of multiculturalism, there has been a return to assimilation policies and that approval for neo-assimilation trends permeates the current discourse in Europe ${ }^{14}$. Cities should, however, be seen as a separate space for making decisions on integration issues. Based on research on urban policies, Maurizio Ambrosini and Paolo Boccagni indicate that multicultural policies in their various options may, in fact, be approved and implemented in some cities. However, they are increasingly limited by anti-immigrant attitudes and budgetary restrictions. ${ }^{15}$

Today, most major European cities adapt to "cultural diversity", "interculturalism", "intercultural dialogue", "social cohesion", "inclusion", "non-discrimination" and "participation". ${ }^{16}$ These policies are targeted at the whole community and not just immigrants. European cities are adopting various diversity management strategies aimed at preventing discrimination, marginalization, and segregation of immigrants, building positive relationships between different ethnic groups and stimulating intercultural dialogue.

\section{Urban Versus National Integration Policies}

Sometimes cities implement and follow integration policies different from those at the national level. Local governments are more pragmatic and focused on finding effective solutions as compared to national governments whose operations are highly politicized. ${ }^{17}$ In Amsterdam, for example, at the end of the 1990s, the authorities adopted a diversity policy and applied an intercultural mainstreaming strategy ${ }^{18}$ and a more individualistic approach to integration that seeks to promote the wellbeing of individuals rather than target groups. Diversity policies were

${ }^{13}$ D. Gebhardt, op. cit., p. 861.

${ }_{14}$ M. Ambrosini, P. Boccagni, Urban Multiculturalism beyond the 'Backlash': New Discourses and Different Practices in Immigrant Policies across European Cities, "Journal of Intercultural Studies", no. 36(1)/2015, pp. 35-53.

15 Ibidem, pp. 35-53.

16 Cf.: Eurocities, Cities and Migrants. Implementing the Eurocities Integrating Cities Charter, Brussels 2013.

17 P.W.A. Scholten, Agenda Dynamics and the Multi-Level Governance of Intractable Policy Controversies: The Case of Migrant Integration Policies in the Netherlands, "Policy Sciences", no. 46 (3)/2013, pp. 217-236.

18 M. Borkert, W. Bosswick, F. Heckmann, D. Lüken-Klaßen, Local integration policies for migrants in Europe, Dublin 2007, pp. 37-38. 
a response to the failures of traditional multiculturalism, and probably at the same time meant the rejection of assimilation tendencies observed at the national level. ${ }^{19}$ London is still described as a cosmopolitan and multicultural city despite the fact that national policies are moving away from the multicultural model. ${ }^{20}$ Researchers emphasize that the London approach to diversity is significantly different from the neo-assimilation or integration concepts of the British government. ${ }^{21}$ In Milan, after almost two decades of ignoring the presence of immigrants, the local administration appointed a permanent assembly of representatives of migrant and ethnic associations. The creation of the assembly was according to Robert Marzorati and Fabio Quassoli - a local multicultural policy. However, it collided with the approach of the city council departments, which were influenced by the national trend of implementing the concept of "integration", commonly defined as a two-way process of mutual adaptation of immigrants and the host society. The city council wanted to implement an intercultural approach to diversity, perceived as "overpowering" a multicultural approach. As Roberta Marzorati and Fabio Quassoli emphasize: "The Milanese case shows that not only are urban immigrant policies independent from national integration policies (...) but different discourses and relative initiatives can cohabit in the same municipality". ${ }^{22}$

Sometimes cities adopt policies on the integration of immigrants as a result of the absence of such policies at the national level. In the UK, for example, many local government units have developed their own visions of inclusion, despite the lack of top-down guidelines. ${ }^{23}$ Berlin formulated integration policies (in the 1980s) before the same was done by the national government (similar to other cities such as Zurich, Basel, Vienna, Rotterdam, Amsterdam, Frankfurt, Turin), mainly to overcome the problems arising from the significant influx of immigrants. ${ }^{24}$ Berlin's

${ }^{19}$ Cf. J. Uitermark, U. Rossi, H. van Houtum, Reinventing Multiculturalism: Urban Citizenship and the Negotiation of Ethnic Diversity in Amsterdam, "International Journal of Urban and Regional Research", vol. 29(3)/2005, pp. 622-640.

${ }^{20}$ E. Collett, M. Petrovic, op. cit., p. 7.

${ }_{21}$ M. Raco, J. Kesten, C. Colomb, Urban Policies on Diversity in London, Bartlett School of Planning, University College London, London 2014, p. 27.

22 R. Marzorati, F. Quassoli, Governing diversity in Milan "città mondo" political discourse and policies towards 2015 EXPO, http://www.rc21.org/en/wp-content/ uploads/2014/12/G3-Marzorati.Quassoli.pdf (access 20.04.2018).

${ }^{23}$ E. Collett, M. Petrovic, op. cit., p. 13.

${ }^{24}$ E. de Graauw, F. Vermeulen, Cities and the politics of immigrant integration: a comparison of Berlin, Amsterdam, New York City, and San Francisco, "Journal of Ethnic and Migration Studies”, vol. 42, no. 6/2016, pp. 993-996. 
current policy emphasizes mutual understanding and relationship building and sees integration as a two-way process in which immigrant organizations play an important role in connecting immigrant minorities with the host society. Compared to German national integration policies, Berlin policies are more inclusive and sensitive to the needs and problems of residents with a migrant background..$^{25}$ However, cities do not always take an inclusive approach to the integration of immigrants. Research on Rotterdam's policies from the first decade of this century has shown that the city has been introducing policies that prevent immigrants access to their rights. ${ }^{26}$

As can be seen from the presented urban policies, the national context alone does not explain the integration policies adopted in European cities. The presented cities have extensive experience with immigrants, but they are not the only cities with a large immigrant population. As indicated in the introduction, due to the research deficit there is a need for comparative studies on local integration policies in more cities and in different national contexts. Various opinions are presented in the literature. Maurizio Ambrosini and Paolo Boccagni, assessing the extent to which national integration policies and discourses influenced urban policy in eight European cities, concluded that public policies at the local level are in many ways independent of national integration philosophies. ${ }^{27}$ Other researchers do not agree that cities and countries differ in their policy of integrating immigrants ${ }^{28}$ sometimes research findings are ambiguous. ${ }^{29}$

\section{Urban Integration Initiatives in Poland}

Although the integration of immigrants in the current legal status is not the task of local governments, some large cities have taken first actions in the field of diversity management using EU funds. They do not result from challenges, but rather from the availability of European money and trends towards cultural diversity. As in other Western European cities, the terms "diversity", "non-discrimination", "social cohesion",

${ }^{25}$ Ibidem, p. 1006.

26 P. Scholten, The Multilevel Governance of Migrant Integration: A Multilevel Governance Perspective on Dutch Migrant Integration Politics", in: The Discourses and Politics of Migration in Europe, eds. U. Korkut et al., New York 2013, pp. 151-170.

27 M. Ambrosini, P. Boccagni, op. cit., pp. 35-53.

28 R. Dekker, H. Emilsson, B. Krieger, P. Scholten, A Local Dimension of Integration Policies? A Comparative Study of Berlin, Malmö, and Rotterdam, "International Migration Review", no. 49 (3)/2015, pp. 633-658.

29 S. Scuzzarello, Policy Actors' Narrative Constructions of Migrants' Integration in Malmö and Bologna, "Ethnic and Racial Studies", no. 38 (1)/ 2015, pp. 57-74. 
"participation", "interculturalism" and "intercultural dialogue" are becoming a label for integration projects and initiatives. Lublin and Warsaw excel in integration initiatives. As part of the Lublin Development Strategy for 2013-2020, the city undertakes activities in the field of immigrant integration aimed at achieving social cohesion. As part of the project Lublin for Everyone. A Participatory Model of Managing the City's Cultural Diversity, cooperation was established between local institutions, non-governmental organizations and other entities dealing with various aspects of providing services to foreigners. ${ }^{30}$ Lublin as the only city in Poland participated (2008-2013) in the program of the Council of Europe and the European Commission - Intercultural Cities, whose main goal was to promote the model of managing cultural diversity (called intercultural integration) in European cities. As a result of actions aimed at building good relations between various groups of the inhabitants of Lublin, the city succeeded in involving native residents as well as students, including those from third countries in the integration process. ${ }^{31}$

As compared to other cities, most integration initiatives are in Warsaw. This is mainly due to the concentration of immigrants in this city and its surroundings. In 2012, the Social Dialogue Commission for Foreigners was established at Warsaw City Hall. In 2014, the city established a Multicultural Centre, whose main goals are to activate and support immigrants, foster integration with the inhabitants of Warsaw, strengthen multicultural dialogue and prevent discrimination and social exclusion. The city supports integration activities, intercultural dialogue, and intercultural education. It also works to prevent discrimination and social exclusion..$^{32}$ By 2018, Krakow, in cooperation with the Association of Interkulturalni.pl, had developed and implemented a "Strategy for the Prevention of and Response to Racist and Xenophobic Events in the City's Public Space”. Under this strategy, a large part of the activities in the field of immigrant integration was undertaken. The city of Bialystok established a team for preventing racial discrimination, xenophobia, and intolerance. Moreover, the "Bialystok for Tolerance" program was adopted. In Wroclaw, there is a team for intercultural dialogue. In Gdansk in 2015, the first team in Poland was created to develop a model of immigrant integration. The team's work resulted in the decision to reject the model

30 R. Stefańska, Integration Policy and Activities in Poland, Migration Policy Centre, INTERACT Research Report, Country Reports, 2015/07.

31 M. Pawlak, M. Bieniecki, Wspólnie przeciw wykluczeniu imigrantów (Together against the Exclusion of Immigrants), „Biuletyn Migracyjny”, no. 33/2012, p. 4.

${ }^{32}$ Fundacja Inna Przestrzeń, Miasta otwarte - Open Cities, p. 30, http://www.politykimigracyjne.pl/images/fora/Raport_Miasta_Otwarte.pdf (access 6.02.2018). 
of "assimilation" and "separation" (a lack of integration, the creation of ghettos). It has been assumed that integration as a bilateral process means including immigrants in the social life of Gdańsk while maintaining their identity and a respect for cultural diversity. ${ }^{33}$ In 2017 the mayors of the biggest twelve cities signed the Declaration of Mayors on Cooperation between the Cities of the Union of Polish Metropolises in the Area of Migration.

The undertaken initiatives demonstrate that Poland's major cities are open to migration processes and the diversity of their residents. It is worth emphasizing, however, that due to the migration and refugee crisis and terrorist attacks, Polish people's support for receiving refugees (immigrants) from the Middle East and Africa has dropped dramatically. As far as the problem of compliance of urban integration policies with Polish national policy is concerned, it should be stressed that in our country, issues related to the integration of immigrants have long been neglected by national authorities due to the marginal scale of immigration and the lack of strong ethnic and cultural tensions. Assessing the immigrant integration model in 2006, Aleksandra GrzymałaKazłowska and Agnieszka Weinar described Poland's integration policy as "assimilation through abandonment". ${ }^{34}$ Nevertheless, the first decade of the 21 st century saw integration programs which became the first stable tool of the state integration policy financed from the central budget, yet implemented at a local level. Foreigners who had obtained refugee status or had been granted subsidiary protection gained the right to apply to the poviat staroste (Head of Poviat) for an individual integration program (IPI). It is implemented by poviat family support centres and supervised by the Minister of Family, Labour and Social Policy. ${ }^{35}$

In recent years, interest in the problems related to immigrant integration has increased significantly, mainly due to the EU funds dedicated to the research into these issues and to measures for the integration of immigrants. ${ }^{36}$ Presented in 2013, the draft document referring to Polish

${ }_{33}$ Zespół ds. Modelu Integracji Imigrantów w Gdańsku (Team for the Model of Immigrant Integration in Gdańsk), Model Integracji Imigrantów (Immigrant Integration Model), http://www.gdansk.pl/urzad/prasa,1060,39669.html (access 1.03.2018).

34 A. Grzymała-Kazłowska, A. Weinar, The Polish Approach to Integration, "Canadian Diversity", vol. 5(1)/2006.

${ }^{35}$ Assistance under IPI depends - at least in theory - on active participation in the integration program and fulfilling the obligations resulting from the integration contract. Studies and reports (including the Supreme Audit Office) point to the insufficient effectiveness of these programs.

${ }^{36}$ M. Lesińska, Polityka integracyjna (Integration Policy), in: Transformacja nieoczywista. Polska jako kraj imigracji (Non-obvious transformation. Poland as a country of immi- 
policy on the integration of foreigners - assumptions and guidelines - states that: "Integration is a complex and dynamic bilateral process involving both foreigners and the host society, whose goal is full and equal membership of foreigners in the society of the host country". ${ }^{37}$ The presented urban initiatives indicate that some large cities have taken action that fit into the "integration" model defined in the national document and implement the concepts of policies pursued in large European cities. It should be mentioned that after 2015, the new right-wing conservative government of the Law and Justice party annulled its strategic documents, and the evolving development of the integration policy in Poland ceased. ${ }^{38}$ Since then, Poland has remained without a strategic document in the area of migration..$^{39}$ Moreover, between 2015 and 2019 competitions for funding projects within the Asylum, Migration, and Integration Fund (AMIF) were either cancelled or suspended. As a result, most NGOs supporting immigrants were forced to curb their activities or even close their programs. ${ }^{40}$ Despite these circumstances, large cities continued and undertook new initiatives in the area of immigrant integration. For this reason, at present, local integration policies are not part of general national strategy.

\section{The Growing Role of Cities or the Centralization of Integration Policies}

It is currently observed that the role of cities in managing immigrant integration is growing, while the state has lost its monopoly in this area. Local management practices and strategies have been recognized by EU

gration), eds. A. Górny, I. Grabowska-Lusińska, M. Lesińska, M. Okólski, Warszawa 2010, p. 108.

37 Ministerstwo Pracy i Polityki Społecznej (Ministry of Labor and Social Policy), Polska polityka integracji cudzoziemców - zatożenia i wytyczne, Projekt (Polish policy on the integration of foreigners - assumptions and guidelines, Project), Warszawa 25th Sept. 2013, p. 4.

38 D. Wach, Evolution of Polish integration policy after 1989, in: Polityka migracyjna w obliczu wspótczesnych wyzwań. Teoria i praktyka, eds. H. Chałupczak, M. Lesińska, E. Pogorzała, T. Browarek, Wydawnictwo Uniwersytetu Marii Curie-Skłodowskiej, Lublin 2018, pp. 347-367.

39 The initial version of the document on Poland's migration policy was presented in June 2019, https://interwencjaprawna.pl/wp-content/uploads/2019/06/Politykamigracyjna-Polski-wersja-ostateczna.pdf (access 29.05.2020).

${ }^{40} \mathrm{M}$. Okólski, D. Wach, Immigration and integration policies in the absence of immigrants. A case study of Poland, in: Relations between Immigration and Integration Policies in Europe, eds. M. Duszczyk, M. Pachocka, D. Pszczółkowska, Routledge, London 2020, p. 162. 
institutions as a major tool for identifying, developing, and promoting new integration models in Europe. The European Parliament pointed out that cities are to play a key role in the integration of immigrants ${ }^{41}$ and the Council of the EU postulated that local government should be given more competence to better manage diversity and combat xenophobia and all forms of discrimination. The Committee of the Regions demanded that local and regional authorities participate in the creation of a European legal immigration framework and in the fight against illegal immigration..$^{42}$ Researchers argue that cities and city networks influence the decision-making process at an EU level bypassing the national level. They strengthen their position by using the space created for them in the multi-level governance model. ${ }^{43}$ Researchers emphasize that in many European countries we can observe "shifts away from historically grounded state-centric policies towards integration strategies developed and implemented at the local level (cities and local governments)". ${ }^{44}$

Therefore, it would seem that states are gradually transferring control over integration policy to local governments. However, the trend towards delegating authority to the local level is not clear. European migration policy strengthens nation states as the main actor in matters of integration. ${ }^{45}$ Dirk Gebhardt's research shows that most European countries are becoming "more active in controlling immigrant integration at both European and national level," and the civic integration programs are a vector of this trend. ${ }^{46}$ Under these programs, newcomers are required to learn the language, history, culture, institutions and standards of a host country, and to pass citizenship tests. ${ }^{47}$ Analyzing the impact of civic integration programs on the role of cities in integration policies,

${ }^{41}$ European Parliament, Resolution of 14 March 2013 on the Integration of Migrants, Its Effects on the Labour Market and the External Dimension of Social Security Coordination, 2012/2131(INI), Strasbourg 14.3.2013.

42 Dziennik Urzędowy Unii Europejskiej C 277, Opinia Komitetu Regionów „Globalne podejście do kwestii migracji i mobilności” (2012/C 277/02), 13.9.2012 (Official Journal of European Union C 277, Opinion of the Committee of the Regions "A global approach to migration and mobility" (2012/C 277/02), 13.9.2012.

${ }_{43}$ P.M. Protasiewicz, Rosnqca rola (The Growing Role), op. cit., pp. 75-97.

44 M. Gońda, M. Lesińska, M. Pachocka, Relations between immigration and integration policies in postwar Europe, in: Relations between Immigration and Integration Policies in Europe, eds. M. Duszczyk, M. Pachocka, D. Pszczółkowska, Routledge, London 2020, pp. 24-45.

${ }^{45}$ M. Borkert, T. Caponio, op. cit., pp. 11-13.

${ }^{46}$ D. Gebhardt, op. cit., p. 743.

47 K. Banting, W. Kymlicka, Is There Really a Backlash Against Multiculturalism Policies? New Evidence from the Multiculturalism Policy Index, "GRITIM Working Paper Series", no. 14/2012, p. 5. 
Dirk Gebhardt concluded that in the Netherlands, these programs led to a centralized enforcement of integration and that cities became merely the executors of Dutch immigrant integration policy. With time, more and more state control over urban implementation appeared, and since 2013 the state has deprived cities of most of their integration management instruments. ${ }^{48}$ As a result of German civic integration programs (called "integration courses") introduced in 2005, municipalities were deprived of most instruments of integration policy, while the state - as Dirk Gebhardt claims - became the main actor of integration policies. In Sweden, civic integration programs established for refugees were mainly focused on accelerating integration in the labour market through their more centralized implementation. Local authorities previously providing labour market services for refugees have, in fact, lost their competence. However, the municipalities were responsible for providing Swedish language courses and an orientation course (offered according to a rigid national framework). For immigrants other than refugees, cities continue to play a coordinating role. They also provide courses as well as orientation and employment programs. ${ }^{49}$

According to research by Dirk Gebhardt, civic integration programs have centralized integration policies in all three countries. As a result, the role of cities in integration policies has been reduced (in Sweden's case) or has even disappeared (as in the Netherlands and Germany). ${ }^{50}$ As Dirk Gebhardt claims, Danish, Flemish, and new Catalan civic integration programs also indicate the decrease in the scope of the city's possibilities to take action. All of this challenges the thesis about the growing role of cities in the integration of immigrants. Another common yet noteworthy feature of implementing civic integration programs as identified by Dirk Gebhardt, is the tendency to replace the cooperation of central government with cities by the cooperation with the market or actors from the third sector operating in accordance with the principles of contracting services. Dirk Gebhardt described this trend as a transfer from multilevel governance to public-private partnerships. ${ }^{51}$ In the Netherlands, for example, private training course providers have completely eliminated public (municipal) adult education centres, and civic integration programs that were initially implemented jointly by the state and cities are now implemented through public-private partnerships.

\footnotetext{
${ }^{48}$ D. Gebhardt, op. cit., p. 747.

${ }^{49}$ Ibidem, p. 749.

${ }^{50}$ Ibidem, p. 754.

${ }^{51}$ Ibidem, p. 750.
} 


\section{Conclusions}

Cities play an important role in integrating immigrants and promoting social cohesion. Local authorities have an advantage over state authorities in such areas as mobilizing immigrants and civil society organizations, properly defining priorities, monitoring the results of integration policy or the use of tools to promote integration..$^{52}$ Research indicates that the running of civic integration programs by the state contradicts the thesis of the growing role of cities in developing immigrant integration policies. These programs have resulted in the centralization of integration policies and the reduction of the role of cities.

In recent years, some European large cities have been implementing a cultural diversity management model known as "intercultural integration". Concepts such as "cultural diversity", "interculturalism", "intercultural dialogue", "social cohesion", "inclusion", "non-discrimination" and "participation" are being developed. Mainstream policies targeted at the entire population have also been adopted. The creation and implementation of integration policy is part of the governance model which involves the cooperation of many private, social and public actors. It should be emphasized, however, that many European cities have not taken action to develop effective integration policies..$^{53}$

Recently, large Polish cities have been undertaking activities that can be defined as part of a two-way integration process. Concepts such as "intercultural diversity", "intercultural dialogue" and "diversity" that have appeared in Western European cities in recent years are used by Polish cities to define the policy of immigrant integration. Thus, Polish cities are following a pattern set by their Western European counterparts. It is worth emphasizing that not every practice that works abroad can be transferred to Polish cities due to differences in migration policy systems or significantly different migration situations.

Cities can create and implement integration policies different from those at a national level. Urban policy is influenced not only by local context, but also by specific national conditions. Cities are in a special situation in facing the demands of residents and having to deal with many problems such as housing, employment and social cohesion. Cities also have to reconcile their policies with the mechanisms imposed by the national framework in which they operate. Therefore, they sometimes significantly modify national policy in order to meet any challenges.

${ }^{52}$ R. Penninx, op. cit., pp. 28-30.
53 Ibidem, pp. 21-37. 
National experience is, in turn, influenced by local experience. Integration policy is, therefore, the result of two-way and multi-level dynamic interactions.

\section{References}

Alexander M.A., Local Policies toward Migrants as an Expression of HostStranger Relations: A Proposed Typology, "Journal of Ethnic and Migration Studies", no. 29 (3)/2003, DOI: https://doi.org/10.1080/13691830 305610.

Ambrosini M., Boccagni P., Urban Multiculturalism beyond the 'Backlash'. New Discourses and Different Practices in Immigrant Policies across European Cities, "Journal of Intercultural Studies", no. 36(1)/2015, DOI: https://doi.org/10.1080/07256868.2014.990362.

Banting K., Kymlicka W., Is There Really a Backlash Against Multiculturalism Policies? New Evidence from the Multiculturalism Policy Index, “GRITIM Working Paper Series”, no. 14/2012.

Borkert M., Caponio T., Introduction: the local dimension of migration policymaking, in: The Local Dimension of Migration Policymaking, eds. T. Caponio, M. Borkert, Amsterdam University Press, Amsterdam 2010, DOI: https://doi.org/10.5117/9789089642325.

Borkert M. et al., Local integration policies for migrants in Europe, European Foundation for the Improvement of Living and Working Conditions, Dublin 2007.

Collett E., Petrovic M., The Future of Immigrant Integration in Europe. Mainstreaming Approaches for Inclusion, Migration Policy Institute, Brussels 2014.

Dekker R. et al., A Local Dimension of Integration Policies? A Comparative Study of Berlin, Malmö, and Rotterdam, "International Migration Review", no. 49 (3)/2015, pp. 633-658, DOI: https://doi.org/10.1111/imre.12133.

Dziennik Urzędowy Unii Europejskiej C 277, Opinia Komitetu Regionów „Globalne podejście do kwestii migracji i mobilności” (2012/C 277/02), 13. 9. 2012 (Official Journal of European Union C 277, Opinion of the Committee of the Regions "A global approach to migration and mobility" (2012/C 277/02), 13.9.2012.

Cities and Migrants. Implementing the Eurocities Integrating Cities Charter, Brussels 2013.

European Parliament, Resolution of 14 March 2013 on the Integration of Migrants, Its Effects on the Labour Market and the External Dimension of Social Security Coordination, 2012/2131(INI), Strasbourg 14.3.2013. 
Florczak A., Ewolucja polityki azylowej Polski. Od internacjonalizacji do przeciweuropeizacji (Evolution of Polish Asylium Policy. From Internationalization to Anti-europeization), „Studia Politicae Universitatis Silesiensis”, vol. 27, Wydawnictwo Uniwersytetu Śląskiego, Katowice 2019.

Fundacja Inna Przestrzeń, Miasta otwarte - Open Cities, http://www.politykimigracyjne.pl/images/fora/Raport_Miasta_Otwarte.pdf (access 6.02.2018).

Gebhardt D., Re-thinking urban citizenship for immigrants from a policy perspective: the case of Barcelona, "Citizenship Studies", vol. 20, no. 6-7/2016, DOI: https://doi.org/10.1080/1369183X.2015.1111132.

Gebhardt D., When the state takes over: civic integration programmes and the role of cities in immigrant integration, "Journal of Ethnic and Migration Studies", vol. 42, no. 5/2016.

Gońda M., Lesińska M., Pachocka M., Relations between immigration and integration policies in postwar Europe, in: Relations between Immigration and Integration Policies in Europe, eds. M. Duszczyk, M. Pachocka, D. Pszczółkowska, Routledge, London 2020.

Graauw de E., Vermeulen F., Cities and the politics of immigrant integration: a comparison of Berlin, Amsterdam, New York City, and San Francisco, "Journal of Ethnic and Migration Studies", vol. 42, no. 6/2016, DOI: https://doi.org/10.1080/1369183X.2015.1126089.

Grzymała-Kazłowska A., Weinar A., The Polish Approach to Integration, "Canadian Diversity", vol. 5(1)/2006.

Lesińska M., Polityka integracyjna (Integration Policy), in: Transformacja nieoczywista. Polska jako kraj imigracji (Non-obvious transformation. Poland as a country of immigration), eds. A. Górny et al., Wydawnictwa Uniwersytetu Warszawskiego, Warszawa 2010.

Marzorati R., Quassoli F., Governing diversity in Milan ,città mondo": political discourse and policies towards 2015 EXPO, http://www.rc21.org/en/wp-content/uploads/2014/12/G3-Marzorati.Quassoli.pdf (access 20.04.2018).

Matusz-Protasiewicz P., Rosnaca rola poziomu lokalnego w kreowaniu polityki integracji imigrantów w Unii Europejskiej (The Growing Role of the Local Level in the Development of Immigrant Integration Policy in the European Union), „Central and Eastern European Migration Review”, vol. 2, no. $2 / 2013$.

Matusz-Protasiewicz P., Sposób ksztattowania relacji międzygrupowych na poziomie lokalnym, ze szczególnym uwzględnieniem spoteczności muzutmańskiej na przyktadzie Antwerpii (Belgia) i Amsterdamu (Holandia). Doświadczenia $z$ badania CLIP 2009-2011 [A way of developing intergroup relations at the local level, with particular emphasis on the Muslim community using the example of Antwerp (Belgium) and Amsterdam (Netherlands). 
Experiences from the CLIP 2009-2011 study], in: Wokót problematyki migracyjnej. Kultura przyjęcia (Around Migration Issues. The Culture of Immigrant Reception), eds. J. Balicki, M. Chamarczuk, Vol. 7, Międzyinstytutowy Zakład Badań nad Migracją Uniwersytet Kardynała Stefana Wyszyńskiego, Warszawa 2013.

Ministerstwo Pracy i Polityki Społecznej, Polska polityka integracji cudzoziemców - zatożenia $i$ wytyczne, Projekt (Polish policy on the integration of foreigners - assumptions and guidelines, Project), Warszawa 25.9.2013.

Okólski M., Wach D., Immigration and integration policies in the absence of immigrants. A case study of Poland, in: Relations between Immigration and Integration Policies in Europe, eds. M. Duszczyk, M. Pachocka, D. Pszczółkowska, Routledge, London 2020.

Pawlak M., Bieniecki M., Wspólnie przeciw wykluczeniu imigrantów (Together against the Exclusion of Immigrants) „Biuletyn Migracyjny”, no. 33/2012.

Penninx R., Decentralizacja polityk integracyjnych. Zarzadzanie migracja $w$ miastach, regionach $i$ spotecznościach lokalnych (Decentralising Integration Policies. Managing Migration in Cities, Regions and Localities), in: Laboratoria integracji. Obserwacje i notatki praktyczne (Integration Laboratories. Observations and Practical Notes), eds. M. Bieniecki, M. Pawlak, ZW CHEMPRESS-SITPChem, Gliwice 2012.

Raco M., Kesten J., Colomb C., Urban Policies on Diversity in London, Bartlett School of Planning, University College London, London 2014.

Rajca L., Rola miast w integracji imigrantów - koncepcje miejskiej polityki integracyjnej (The role of cities in the integration of immigrants - concepts of urban integration policy), „Samorząd Terytorialny”, no. 7-8/2018.

Schiller M., Paradigmatic Pragmatism and the Politics of Diversity, "Ethnic and Racial Studies", no. 38 (7)/2015, DOI: https://doi.org/10.1080/014 19870.2014.992925.

Schiller M., European Cities, Municipal Organizations and Diversity. The New Politics of Difference, Palgrave, London 2016, DOI: https://doi. org/10.1057/978-1-137-52185-9.

Scholten P.W.A., Agenda Dynamics and the Multi-Level Governance of Intractable Policy Controversies: The Case of Migrant Integration Policies in the Netherlands, "Policy Sciences", no. 46 (3)/2013, DOI: https://doi. org/10.1007/s11077-012-9170-x.

Scholten P.W.A, The Multilevel Governance of Migrant Integration: A Multilevel Governance Perspective on Dutch Migrant Integration Policies, in: The Discourses and Politics of Migration in Europe, eds. U. Korkut et al., Palgrave, New York 2013, DOI: https://doi. org/10.1057/9781137310903_9. 
Scuzzarello S., Policy Actors' Narrative Constructions of Migrants' Integration in Malmö and Bologna, "Ethnic and Racial Studies", no. 38 (1)/2015, DOI: https://doi.org/10.1080/01419870.2013.848287.

Stefańska R., Integration Policy and Activities in Poland, Migration Policy Centre, INTERACT Research Report, Country Reports, 2015/07.

Stefańska R., Między multikulturalizmem a asymilacją? Polityki integracyjne $w$ Europie (Between Multiculturalism and Assimilation? Integration Policies in Europe), in: Problemy integracji imigrantów. Koncepcje, badania, polityki (Problems of Immigrant Integration. Concepts, Research, Policies), eds. A. Grzymała-Kazłowska, S. Łodziński, Wydawnictwa Uniwersytetu Warszawskiego, Warszawa 2008.

Uitermark J., Rossi U., Hank van H., Reinventing Multiculturalism: Urban Citizenship and the Negotiation of Ethnic Diversity in Amsterdam, "International Journal of Urban and Regional Research", vol. 29(3)/2005, DOI: https://doi.org/10.1111/j.1468-2427.2005.00614.x.

Wach D., Evolution of Polish integration policy after 1989, in: Polityka migracyjna w obliczu wspótczesnych wyzwań. Teoria i praktyka, eds. H. Chałupczak, M. Lesińska, E. Pogorzała, T. Browarek, Wydawnictwo Uniwersytetu Marii Curie-Skłodowskiej, Lublin 2018.

Zespół ds. Modelu Integracji Imigrantów w Gdańsku, Model Integracji Imigrantów (Immigrant Integration Model), http://www.gdansk.pl/urzad/ prasa,1060,39669.html (access 1.03.2018). 